\title{
Coping Strategies and Subjective Well-being in Undergraduate Students
}

\author{
Sindy Setiawan \\ sindysetiawan@gmail.com \\ Industrial and Organization Psychology, Gunadarma University \\ Graha Simatupang Tower 1A, Jl. Letjen Tb. Simatupang Kav. 38 Jakarta Selatan
}

\begin{abstract}
.
Coping strategies are assumed to be able to improve subjective well-being in undergraduate students who spend time in their education at universities. The purpose of this study is to find out whether coping strategies affect subjective wellbeing of undergraduate students. This study involved 60 undergraduate students. In this study used the multiple regression hypothesis test. The results showed that there was no effect of coping strategies on subjective well-being, even though the problem focused coping was more in increasing one's subjective well-being.
\end{abstract}

Keywords: coping strategies, subjective well-being, undergraduate student

\section{Introduction}

Education is one of the most important elements in a person's life. Education consists of formal and informal education. Formal education such as Kindergarten, Elementary School, Junior High School, Senior High School and then there is also the University. On the other hand, informal education such as English courses, abacus courses and others. At the Kindergarten and Elementary School levels, they are still studying basic or general subjects. Meanwhile, at the Senior High School and University levels, they start to enter difficult times in gaining knowledge in terms of learning.

The process from studying in Kindergarten, Elementary School, Junior High School and Senior High School to studying in Universities is certainly not easy. Continuing education to University is an achievement for every individual. 
Therefore, individuals who can continue their studies to a higher level, namely University, must feel happy or satisfied because being able to get to a higher level is a part of an achievement since not everyone can continue their studies at Universities to achieve their goals. Mujamiasih (2013) used the term subjective well-being to describe a person's happiness or life satisfaction.

Subjective well-being is a form of evaluation about the individual's life. This form of evaluation can be carried out in two ways, namely cognitive assessment and emotional response to events (Diener, 2002). Individuals who are able to evaluate their life satisfaction are able to control their emotions and deal with various events in life better, while individuals who are unable to evaluate their lives tend to look down on their lives and perceive events that occur as unpleasant. This is what causes unpleasant emotions such as anxiety, stress, and anger (Diener, 2000).

By reviewing the process from Kindergarten to Senior High School, it can be said that these times are not that difficult to pass. Actually, the same also goes with University. There is nothing difficult in studying. It is just that it requires a little more maximum effort to continue to gain knowledge, achievements and maximum results in the future. If at the Elementary School to Senior High School level a person only deals with fairly simple tasks, it is different from University which requires individuals to be able to solve many problems that are much more complex and varied. Sometimes this fact is what makes undergraduate students feel disappointed because they expect that while in Universities they will avoid many and difficult assignments, but in fact, during studying in University they are given endless assignments and have a high enough level of difficulty. This condition can make undergraduate students feel depressed and experience stress and can affect their subjective well-being.

Not only the many demands of difficult assignments that are a source of stress for undergraduate students. Other things that can trigger undergraduate student stress are internal factors that are very competitive in completing assignments that they seem hasty and lack of deep understanding of the assignment material. In this condition, undergraduate students will spontaneously find a way out or a solution 
to the problems that cause them stress or feel overwhelmed. In psychological terms, ways of solving or overcoming a problem are called stress coping strategies (Santrock, 2005).

Smet (in Rustiana \& Cahyati, 2012) explained that stress is a biopsychosocial tense condition because there are many developmental tasks dealt by people every day, whether in peer groups, family, school or work. Braznitz and Golberger's research (in Rahayu \& Suhayat, 2011) also stated that each individual has a different stress threshold because individual characteristics will also influence the level of stress they experience. Therefore each undergraduate student has their own strategy or way of dealing with stressors. Lazarus (1993) distinguished coping strategies into two, namely coping strategies that focus on problems (problem focused coping) and coping strategies that focus on emotions (emotion focused coping). Each undergraduate student can use problem focused coping or emotion focused coping to deal with the stress they are experiencing. So that the impact can also be different between undergraduate students who use problem focused coping and emotion focused coping, but both of them increase one's subjective well-being. In accordance with the results of research by Diponegoro (2006) which stated that stress coping is considered to be one of the factors that can increase subjective wellbeing. Supported by the opinion of Compton (2005) which explained that subjective well-being can be seen from how individuals deal with situations or experiences in their life positively, so that the more often individuals deal with pleasant events, the happier they will be.

Based on the descriptions and problems above, the researcher is interested in conducting further research on stress coping strategies on subjective well-being by taking undergraduate students as the subjects, with the research title being Coping Strategies against Subjective Well-being in Undergraduate Students.

\section{Research Method}

This study involved 60 undergraduate students as participants. Participants in this research were undergraduate students from various universities and faculties. Based on this number, 37 of them are female and 23 of them are male. 
Subjective well-being is an evaluation of one's life (Diener, Suh \& Oishi, 1997). In this study, the subjective well-being scale used is The Satisfaction with Life Scale (SWLS) by Diener, Emmons, Larsen and Griffin (1985). One example of an item on this scale is "I am satisfied with my life". The answer choices ranged from 1-7 ranging from Very Unsuitable to Strongly Suitable. This scale has 5 items with a reliability of 0.825 .

Feldman (in Ruliansyah, 2015) explained that a coping strategy is an attempt to control, reduce, or learn to tolerate threats that cause stress. The coping strategy scale used in this study is the coping strategy scale of Carver, Scheier, and Weintraub (1989). This scale is divided into two, namely the scale of problem focused coping and scale of emotion focused coping. On the problem focused coping scale, one example of an item is "I make a plan for action." The answer choices ranged from 1- 4 ranging from Very Unsuitable to Strongly Suitable. This scale originally had 20 items. After going through the calculation of the item's discriminatory power, there are 6 items nulled. The number of items remaining is 14 items with a reliability of 0.804 . On the emotion focused coping scale, an example of an item is "I try to get emotional support from friends or relatives". This scale originally had 20 items. After going through the calculation of the item's discriminatory power, there are 3 items nulled. The number of items remaining is 17 items with a reliability of 0.811 .

This study aims to examine the effect of three variables, namely coping strategies (problem focused coping and emotion focused coping) as the independent variable and the subjective well-being variable as the dependent variable. The data analysis method used is multiple regression test using Statistical Package for Social Sciences (SPSS) 21 software for Windows.

\section{Results}

In the linearity test, it is known that the significance value of the coping strategy variable with subjective well-being is 0.158 above 0.05 , which stated that there is no linear effect. This linear relationship indicates that with or without a 
change in the coping strategy variable, it will not bring any changes to the subjective well-being variable.

Table 1.

Contribution Between Variables

ANOVA $^{\mathrm{a}}$

\begin{tabular}{llrrrrr}
\hline Model & $\begin{array}{c}\text { Sum of } \\
\text { Squares }\end{array}$ & df & $\begin{array}{c}\text { Mean } \\
\text { Squar } \\
\text { e }\end{array}$ & F & Sig. \\
\hline $\begin{array}{l}\text { Regr } \\
\text { essio }\end{array}$ & 122,387 & 2 & 61,194 & 1,9 &, $158^{\mathrm{b}}$ \\
$\mathrm{n}$ & & & & 08 & \\
1 & $\begin{array}{l}\text { Resi } \\
\text { dual }\end{array}$ & 6 & & & & \\
& Tota & 1950,18 & 59 & & & \\
& 1 & 3 & & & & \\
\hline
\end{tabular}

a. Dependent Variable: SWB

b. Predictors: (Constant), EmotionFC, ProblemFC

Based on the results of hypothesis testing, the determinant coefficient was $6.3 \%$, which means that the influence of coping strategies on subjective well-being was $6.3 \%$, while the remaining $93.7 \%$ was influenced by other factors outside of research.

Table 2.

\section{Correlation Coefficient Between Variables}

Model Summary

\begin{tabular}{ccccc}
\hline Model & $\mathrm{R}$ & $\mathrm{R}$ Square & $\begin{array}{c}\text { Adjusted R } \\
\text { Square }\end{array}$ & $\begin{array}{c}\text { Std. Error of } \\
\text { the Estimate }\end{array}$ \\
\hline 1 &, $251^{\mathrm{a}}$ &, 063 &, 030 & 5,663 \\
\hline a. Predictors: (Constant), EmotionFC, ProblemFC
\end{tabular}

Based on the hypothesis test, the results also show that problem focused coping has a beta value of 0.242 and emotion focused coping has a beta value of 0.017. Of the two independent variables, problem focused coping has a value closest to 1 where a variable can be said to be the most influential if it has a beta value of $0<1$. However, the beta value on problem focused coping is still far from what it should be. So it can be concluded that all coping strategies have no effect on subjective well-being. 
Table 3.

\section{Coefficient Table}

\begin{tabular}{|c|c|c|c|c|c|c|}
\hline \multicolumn{7}{|c|}{ Coefficients $\mathrm{s}^{\mathrm{a}}$} \\
\hline \multirow{2}{*}{\multicolumn{2}{|c|}{ Model }} & \multicolumn{2}{|c|}{$\begin{array}{c}\text { Unstandardized } \\
\text { Coefficients }\end{array}$} & \multirow{2}{*}{$\begin{array}{c}\begin{array}{c}\text { Standar } \\
\text { dized } \\
\text { Coeffic } \\
\text { ients }\end{array} \\
\text { Beta }\end{array}$} & \multirow[t]{2}{*}{$\bar{t}$} & \multirow[t]{2}{*}{ Sig. } \\
\hline & & $\mathrm{B}$ & $\begin{array}{c}\text { Std. } \\
\text { Error }\end{array}$ & & & \\
\hline \multirow{3}{*}{1} & $\begin{array}{l}\text { (Const } \\
\text { ant) }\end{array}$ & 10,629 & 8,480 & & $\begin{array}{r}1,25 \\
3\end{array}$ &, 215 \\
\hline & $\begin{array}{l}\text { Proble } \\
\mathrm{mFC}\end{array}$ & ,303 & , 187 & ,242 & $\begin{array}{r}1,62 \\
3\end{array}$ &, 110 \\
\hline & $\begin{array}{l}\text { Emoti } \\
\text { onFC }\end{array}$ & ,020 & , 172 & ,017 &, 114 & ,910 \\
\hline
\end{tabular}

a. Dependent Variable: SWB

Based on the research results, it is generally known that there is no effect of coping strategies on subjective well-being in undergraduate students. This adds to the variation from the findings of previous studies. Although there are many studies that have found the effect of coping strategies on subjective well-being, this study found the opposite. In accordance with the findings of Cohen and Lazarus (1977), it was explained that the effectiveness of coping depends on the success of the coping task that must be fulfilled by the individual himself. Coping cannot be said to be appropriate or inappropriate, wrong or right, good or bad, because a strategy may be effective in certain situations, but not in other situations. Diener and Larsen (1985) also added that a person is said to have high subjective well-being if they rarely experience negative emotions.

Although in this study there is no effect of coping strategies on subjective well-being, it can be said that problem focused coping plays a more important role in increasing subjective well-being. This is consistent with previous research conducted by Dewi and Utami, who found that increasing subjective well-being is influenced by coping strategies that are problem focused coping, because these strategies can reduce sources of stress that cause stress. And supported by the research of Folkman and Lazarus (in Dewi \& Utami) which stated that emotion focused coping will only ease the psychological burden felt by individuals, but does 
not solve the problem because it does not reduce the source of pressure, therefore the relief felt due to emotion focused coping is only temporary, thus in general it does not improve the quality of subjective well-being.

\section{Conclusion and Suggestions}

Coping strategies have no effect on subjective well-being, although problem focused coping plays an important role in increasing subjective well-being than emotion focused coping. This shows that this variable is very dynamic in studentrelated studies and remains valuable in subsequent studies of undergraduate students with different problem contexts or more specific participants.

There are several suggestions that can be made regarding the results of this study. First, increasing the number of participants. Second, broadening the participants equally between universities or faculties. This may be more effective in obtaining more accurate and realistic research results between coping strategies and subjective well-being.

\section{References}

Carver, C. S., Scheier, M. F., \&Weintraub, J. K. (1989). Assessing coping strategies: A theoretically based approach. Journal of personality and social psychology, 56(2), 267-283.

Compton, W. C. (2005). An introduction to positive psychology. US: Thomson Learning, Inc.

Dewi, P. S., \& Utami, M. S. Subjective well being anak dari orang tua yang bercerai. Jurnal psikologi, 35 (2), 194-212.

Diener, E., Suh, E., dan Oishi, S. (1997). Recent findings on subjective well-being. Indian journal of clinical psychology. www.psych.uiuc.edu.

Diener, E., Emmons, R. A., Larsen, R. J., \& Griffin, S. (1985). The satisfaction with life scale. Journal of personality assessment, 49 (1), $71-75$.

Diener, Ed. (2000). Subjective well being: The science of happiness and proposal for the national index. American psychologycal association. Journal of happiness, 55(1), 34-43. 
Diener, E., Lucas, R. E., \& Oishi, S. (2002). Subjective well-being: The science of happiness and life satisfaction. In C. R. Snyder \& S. J. Lopez (Eds.). The handbook of positive psychology. New York: Oxford University Press.

Diponegoro, A. M. (2006). Peran stress management terhadap kesejahteraan subjektif. Humanitas, 3 (2), 137-145.

Lazarus, S., \& Cohen, J. (1977). Environmental stress in J. Wohlwill \& I. Altman (Eds). Human behavior and environment journal, 90 -127. New York: Plenum.

Lazarus, R. S. (1993). From psychological stress to the emotion: A history of changing outlooks. Annual Reviews, 4. 1-21.

Mujamiasih, M., Prihastuty, R., \& Hariyadi, S. (2013). Subjective well being: studi indigenous karyawan bersuku jawa. Journal of social and industrial psychology, 2 (2), $36-42$.

Rahayu, N. I., \& Suhayat, S. H. (2011). Hubungan olahraga rekreasi dan penurunan tingkat stres mahasiswa ilmu keolahragaan. Strengthening research collaboration on education.

Ruliansyah, R. (2015). Meningkatkan strategi coping melalui metode expressive writing dan focus group discussion pada siswa kelas XI SMAN 7 Yogyakarta. E-journal bimbingan dan konseling ed11, 1-12.

Rustiana, E. R., \& Cahyati, W. H. (2012). Hubungan antara stres kerja dengan pemilihan strategi coping pada dosen. Jurnal kesehatan masyarakat, 7 (2), 144-150.

Santrock, J. W. (2005). Psychology (7th Ed). New York: McGraw-Hill Companies. 